\title{
Influence of Parent-Child Interaction on Socio-emotional Development of Children With Perinatal Risks
}

\section{Maria Lavrova, Lyudmila Tokarskaya, and Sergei Kiselev}

Ural federal university named after the first President of Russian B. N. Yeltsin, Yekaterinburg, Russia

\section{Abstract}

The article is devoted to the study of the influence of peculiarities of child-parent interaction on the early socio-emotional development of children with perinatal risks. This is a relevant area since, first of all, there is an increasing number of children with such risks (especially, with the risk of autism spectrum disorders (ASD) and attention deficit hyperactivity disorder (ADHD)). Moreover, it is parents who can be

Corresponding Author:

Maria Lavrova

liydmil@mail.ru

Received: 25 July 2018

Accepted: 9 August 2018

Published: 1 November 2018

Publishing services provided by

Knowledge :

(c) Maria Lavrova et al. This article is distributed under the terms of the Creative common's Attribution License, which permits unrestricted use and redistribution provided that the original author and source are credited.

Selection and Peer-review under the responsibility of the Fifth International Luria Memorial Congress Conference Committee. most instrumental in the successful development, adaptation and socialization of children. The article examines Russian and foreign approaches to the definition of socio-emotional development, stages, and levels of its development. It also analyses the data obtained in the course of research of peculiarities of parent-child interaction with the help of video observation $(\mathrm{PCl})$ that was conducted using the coding scales (SocialinteractionratingScale). In order to assess cognitive, speech, socio-emotional development, and adaptive behavior, «Bayley Scales of Infant Development Third Edition» were used. The data of eight children of the control group (average age 5-8 months) and eight children of the experimental group with family risk of atypical development (older sibling or parent have a confirmed diagnosis of ASD and/or ADHD) (average age 2-66 months) were analyzed. Two-way analysis of variance showed that nondirective behavior of parents can lead to a more successful development of socio-emotional skills of children with the family risk of ASD and ADHD, namely, the skill 'social setting'. The study is a pilot but demonstrates a potential for further research in this area.

Keywords: child-parent interaction, video observation, young children, family risk, socio-emotional development

\section{G OPEN ACCESS}




\section{Introduction}

Despite a recently growing interest in the cognitive development of children, attention to the study of the emotional sphere is not declining. The value of the development of social skills and the emotional sphere is undeniable. As is noted by V.V. Lebedinsky and M.K. Bardyshevskaya, «it is at the young age that the trouble in affective sphere is most malignant for the psychological and psychosomatic development of children». [8, p. 12]

In the past, emotions used to be thought of as «rudiments of human development», yet since the first half of the zoth century researched have noted a significant existing connection between intellectual and emotional spheres [5], which included cognitive component in emotionality: emotional and cognitive spheres together provide orientation in the world around them; apart from that, emotions ensure the vigor of psychological activity $[8,12]$. From this perspective, emotions can also be included in the first functional regulation block of vigor and wakefulness (level of involuntary self-regulation and self-organization) according to A.R. Luria [11].

Nowadays a number of researchers note the impossibility of a child's cognitive development without socio-emotional skills $[6,7]$. Thus, DIR approach, which is gaining popularity in our country, to children with ASD and aimed at their socialization, takes it as the foundation of the floor-time approach. This approach is used when working with young children as well as adolescents and adults. In order to assess the progress, the following criteria are selected: emotional warmth, ability to engage in relationships, creative thinking ability, and meaningful communication ability. The therapy takes place in the atmosphere of emotional contact, where not only specialists participate, but the whole family, as the result communicative and cognitive skills quickly enter the everyday life.

Socio-emotional development is the formation and development of socially significant personality traits during which one masters the following: various ways of emotional response, ability to recognize one's own emotions and control them in different life situations; establishment and maintenance of emotional contact with other people [2]. E.P. Ilyin writes that emotional development of a child happens in a number of ways: overcoming impulsive behavior; emergence of stable emotions alongside situational ones; developing the ability to use emotional expression as a means of communication and recognizing emotion based on facial expressions [7].

One way or another, researchers identify certain age formations in the emotional sphere, presence/distortion/absence thereof can indicate whether the whole process 
of child's development is successful or unsuccessful: consequences of organic brain syndrome; somatic wellbeing; unfavorable upbringing conditions; a child's characterological peculiarities; manifestation of early crisis periods; early disorders and distortions of affective development [3].

The main new formations of the emotional sphere are as follows: a smile; emotional animation complex; babbling; stranger anxiety and separation anxiety; ability to adapt one's emotional state to the mother and perceive her signals during free exploration of the world around; presence of transitional object; emergence of the pronoun «l» in speech as an indicator of psychological separation from the mother; ability to regulate emotions using symbols [8, p. 146].

To be able to objectively assess the wellbeing of the emotional sphere, one must take note of not only asynchrony and length of delay of a formation's emergence, but also determine its quality (the structure of the abnormality). Thus, gross developmental disorders of emotional development accompanied by autism spectrum disorders which are becoming absolutely obvious near the age of 3, often manifest themselves in subtle, nonspecific signs of affective ill-being at the earlier age $[3,8]$.

Normal emotional development requires undergoing certain stages. M.K. Bardyshevskaya and V.V. Lebedinsky [8] look at the affective development through the levels of emotion regulation:

1. level of assessment of intensity of environmental influences;

2. level of affective stereotypes;

3. level of affective expansion;

4. level of basic affective communication;

5. level of symbolic regulation.

According to M.K. Bardyshevskaya and V.V. Lebedinsky, the critical periods of emotional development are $0-3 ; 3-6 ; 6-12 ; 12-18 ; 18-24 ; 24-36,36-42$ months which are distinctive due to the emergence of new formations.

We find the method of diagnosis of the level of emotional sphere development formulated by S. Greenspan particularly interesting. This method is represented in the Bayley Questionnaire for parents as a supplement to the Scales of development of infants and toddlers of Bayley (Bayley Scales of Infant Development, BSIDIII) [18]. In it, he distinguishes the following stages: 
1. Self-regulation and interest in the world (o-3 months). During this stage a child is learning how to interact with other people, focus one's attention on the same thing as the adult, keep calm; get information from communication with the adults and also from one's own sense organs and movements.

2. Interaction stage (contact and communication) (4-5 months): a child starts to differentiate between the caregiving adult and other people; it starts to enjoy the interaction with this adult; it shows interest in inanimate objects. Positive emotions, which a child gets from the caregiver, help it learn to distinguish tones of voice and facial expressions which show feelings and intentions of adults. Thus, the process of learning about the connections between things starts and there is a shift from perception to comprehension of concepts.

3. Intent and two-way communication (6-9 months): a child is purposefully and interactively using emotions. By 6 months, a child starts to translate emotions into communicative signals, while the adult learns to understand and respond to them in such a way that the child, in turn, learns to understand and respond to the adult's signals. In such a way, a child is involved in a system of mutual emotional signals. Having acquired this skill, a child can enter communication without words. Logic and perception of reality emerge at this stage.

4. This stage is characterized by solution of social tasks, mood regulation and formation of self-consciousness (10-18 months). A child is using a series of interactive emotional signals/gestures for communication (it is learning to control its emotions through the use of emotional signs and negotiation with adults) and a little later - for solution of concrete problems (to achieve the desired goal a child starts to use combinations of three or four steps, which will in the future lead to the connection of words into sentences and development of logical thinking). At this stage a child develops a sense of self, it is exploring the properties of the physical world. Observing the patterns, it starts to understand the underlying mechanisms.

5. Formation of symbols and usage of words and notions (19-30 months). The use of symbols and concepts for expression of an intention/feeling and later for other not only basic needs. Thinking with the use of symbols leads to the development of speech and enhances cognitive development.

6. Emotional thinking, logic and a sense of reality (from 31 months). A child creates logical connections between emotions and concepts, it is learning to logically 
connect symbols, classify subjective and objective experience. Logical thinking is conducive to the development of such skills as mathematical problem-solving, argumentation. At this stage, a child can already invent, for instance, rules of the game. S. Greenspan notes that a child with normal development masters six basic stages by the time he is $4-5$ years old, thus building a foundation for further development.

There are 10 scales of adaptive behavior in the questionnaire that assess a child's models of behavior: communication, life in society, functions of the pre- academic period, life at home, health and safety, leisure, self-care, self-regulation, social setting, motor skills.

Researchers, who study children's development on the whole, and emotional one, in particular, one way or another, rely on the global approaches to child development.

Generally speaking, Cambridge Encyclopedia Of Child Development authors write [22] that approaches to child development can be grouped into:

1. «Neuromaturational» theory. Ontogenetic development is taking place as a result of genetically determined structural changes in the central nervous system, which, in turn, can lead to an orderly change in the functional aspect. Any function is developing depending on an inevitable and unchanged linear sequence of certain stages with minimal help (or lack thereof) of the existing setting.

2. Constructivist theories. Based on J. Piaget's ideas [15] where cognitive development includes qualitative and quantitative changes in psychological structures. However, modern constructivism states that these changes are connected with concrete tasks, spheres, and social context. Preserving the principle that individual activity is the central driver of cognitive changes, the modern approach includes biological, psychological and socio-cultural processes as factors facilitating the changes more fully.

3. Ethological theories. The representatives and researchers who used this approach as the basis for their studies are Lorenz K., Ainsworth M., Bowlby J. [9, 10, 17, 19]. These authors conducted research into comparison of animal and human behavior in order to answer the questions about the reasons for, functions, evolution, and peculiarities of development of behavior and made a considerable contribution into the research of child development through studying imprinting and speech.

Thus, the theory of attachment, which is founded on the phenomenon of imprinting, focuses on the quality of a child's attachment depending on the behavior type of the 
parent which can have different effects on the child-care. On the basis of observation, there are three types of child reactions which correspond to three types of attachment of it to the mother. They are insecure-avoidant, secure, insecure-resistant (ambivalent). Later, a disorganized type was described (behavior of infants that display a consistent pattern of behavior when separated from the mother and being subsequently reunited with her); it occurs, as a rule, in dysfunctional relationships with the mother and is connected with violence and psychological traumas in the family [13].

1. Learning theory studies the role of education in child development based on experiments conducted by I. Pavlov, A. Bandura [4, 14].

2. Psychoanalytical theory examines the importance of the early period of child development in the formation of the human psyche. Early experience determines the future peculiarities of interaction of a person with the world and distinctive features of their emotional experience.

There are a number of other meticulously studied approaches [22], but either way, all of them, in both Russian and foreign psychology, stress the importance of parentchild communication in the emotional sphere. S. Greenspan claims that «Speech and human thought, and also emotional and social skills are mastered in the process of relationships which include emotionally significant interaction» [6, p. 40]. The term Parent-Child Interaction, in the broad sense, means the process of organization of collaborative activity of a child and parent [1].

Thus, researchers of various disciplines do not cease to be interested in the development of the emotional sphere of infants and toddlers. Knowledge of stages of its formation and development helps predict abnormalities and conduct early correction. As far as fundamental and applied studies are concerned, it is still vital to research the factors influencing the development of the emotional sphere, one of which is parentchild interaction $(\mathrm{PCl})$.

The study of PCl's impact on child development was conducted using formalized observation. The data of 8 children of control group (average age 5,8 months) and 8 children of experimental group with family risk of atypical development (older sibling or parent has a confirmed diagnosis of ASD and/or ADHD) (average age 6,2 months) were analyzed on the basis of Laboratory of brain and neurocognitive development of the Ural Federal University named after the first President of Russian B. N. Yeltsin (Yekaterinburg) [16].

Identification of the peculiarities of parent-child interaction was made with the analysis of the results of video observation (nowadays it is one of the most widespread 
methods of $\mathrm{PCl}$ study) which was conducted according to the protocol using the coding scales (Social Interaction Rating Scale). The SIRS scale lets us assess the behavior of parents according to the following criteria: «directiveness», «initiation toward the child», «maintenance of interaction with the child», «responsiveness», «engagement», «expressivity», general assessment of the adequacy of interaction. The advantage of SIRS coding system is that it describes the specific behavior of a parent which can be taught in training.

The interaction consists of 2 stages: free play without toys ( 5 minutes) and with toys (5 minutes). The toy set includes: a role-play toy (toy phone with cord), a developmental toy, a book, a building game (construction cubes), a spinning object (a whirlabout), a doll, an animal shaped toy.

The parent is asked to interact with the child naturally as they usually play with it, in a specially equipped, comfortable space with video cameras at different angles recording the sound as well.

The video recordings were analyzed by two psychologists who were unaware of a child's diagnosis and the group they belong to. The data were compared and the discrepancy was not more than $10 \%$. As the result, a profile of parent interaction according to six characteristics and general assessment of adequacy was identified. These six characteristics are scored from 1 to 3 points (0,5 increment) for frequency and quality of manifestation of the characteristic which gives us the opportunity to further unite them into nominal groups according to this feature.

In order to assess the cognitive, speech, socio-emotional development, and adaptive behavior, «Bayley Scales of Infant Development Third Edition» was used (adapted for Russian population of children). Raw data obtained as the result of the testing were transformed into scale points for the particular age, allowing us to compare certain aspects of child development with normal indexes at the current stage of development. This scale is one the most well-known and valid one in diagnostics of specificity of early child development.

Bayley's method consists of four parts, including cognitive, motor, behavioral and a questionnaire on socio-emotional skills and adaptive behavior of a child. The questionnaire allows one to determine the level of socio-emotional development of a child, level of sensor information processing; adaptive skills: «communication», «health and safety», «leisure», «self-care», «self-regulation», «social skills», «motor skills».

The data were analyzed with the use of statistical package SPSS Statistics. Two-way analysis of variance showed the validity of the influence of such parent's behavior as «directiveness» SIRS and the group on the Adaptive Behavior Skill «Social skill» BSID 
TABLE 1: Group/Social skill.

\begin{tabular}{l|l|l}
\hline Parent's directiveness & $\begin{array}{l}1.5 \text { (frequent attempts to } \\
\text { direct the attention, } \\
\text { behavior of the child) }\end{array}$ & $\begin{array}{l}2.5 \text { (parent follows child's } \\
\text { attention; parent redirects } \\
\text { child's attention to another } \\
\text { object only when the focus of } \\
\text { attention is unproductive) }\end{array}$ \\
$\begin{array}{lll}\text { Experimental group } \\
\text { (social skill, raw data) }\end{array}$ & 9.67 & 21 \\
Control group & 16.75 & 15
\end{tabular}

III (F $=5.901 p=0.027)$. Other peculiarities of interaction did not reveal any reliable effect. Figure 1 shows the results of two-way analysis of variance, where $k$-control group, $r$ - experimental group on the horizontal axis; mean index of behavioral skill «Social skill» is on the vertical axis (for directiveness 1.5 and 2.5).

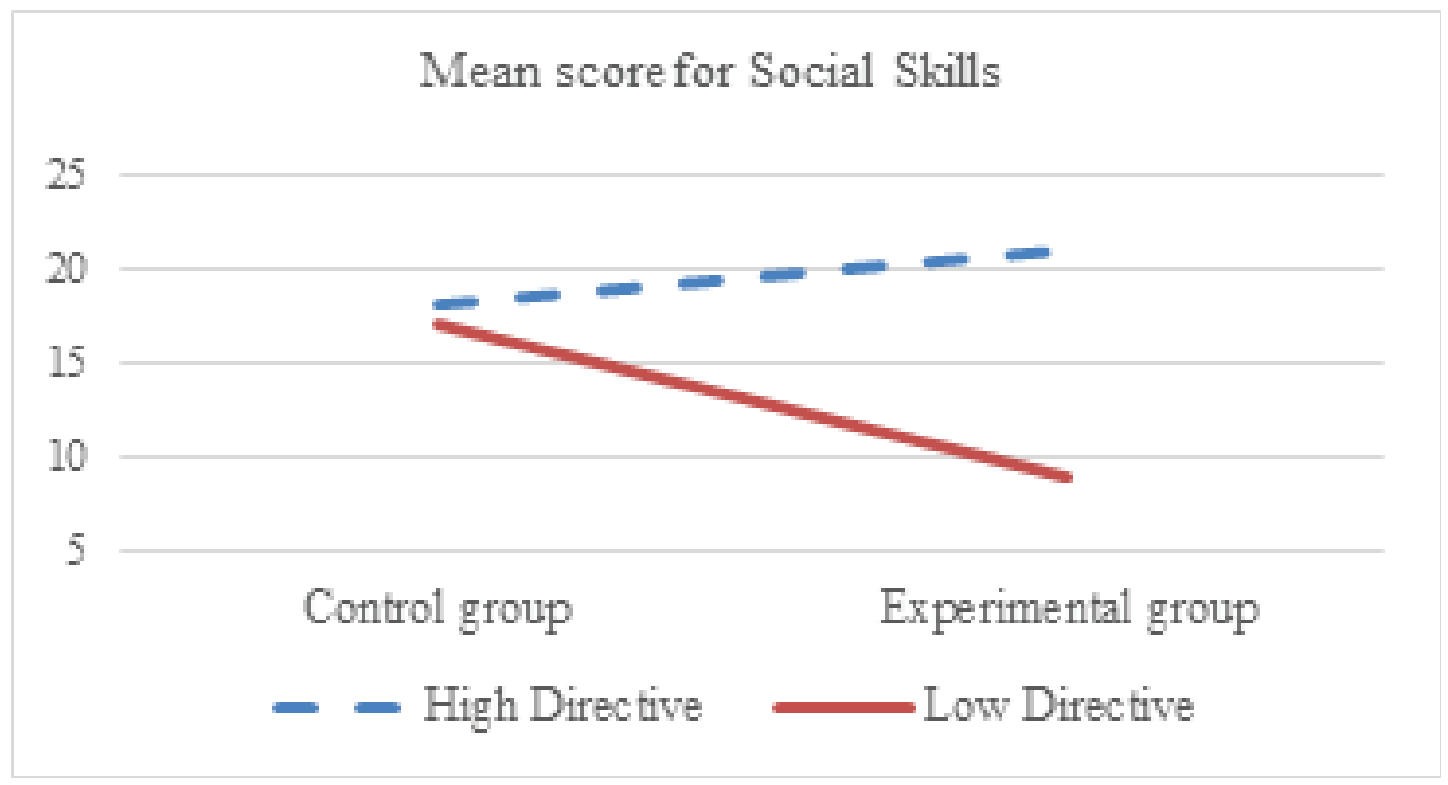

Figure 1: Group/Social skill.

The data presented in Table 1 illustrates the two-way analysis of variance results.

The term directiveness in SIRS means the degree to which a parent gives commands and directs child's attention.

Child's adaptive behavior includes the ability to cope with the requirements of the setting and everyday needs. These skills are intrinsically connected with other areas of development and skills. Growth and development of young children lead to the development of various skills, including communication, social, motor, health and safety, home living, self-care, leisure, community use, functional preacademic, and self-direction. 
TABLE 2: Data of socio-emotional questionnaire BSID III.

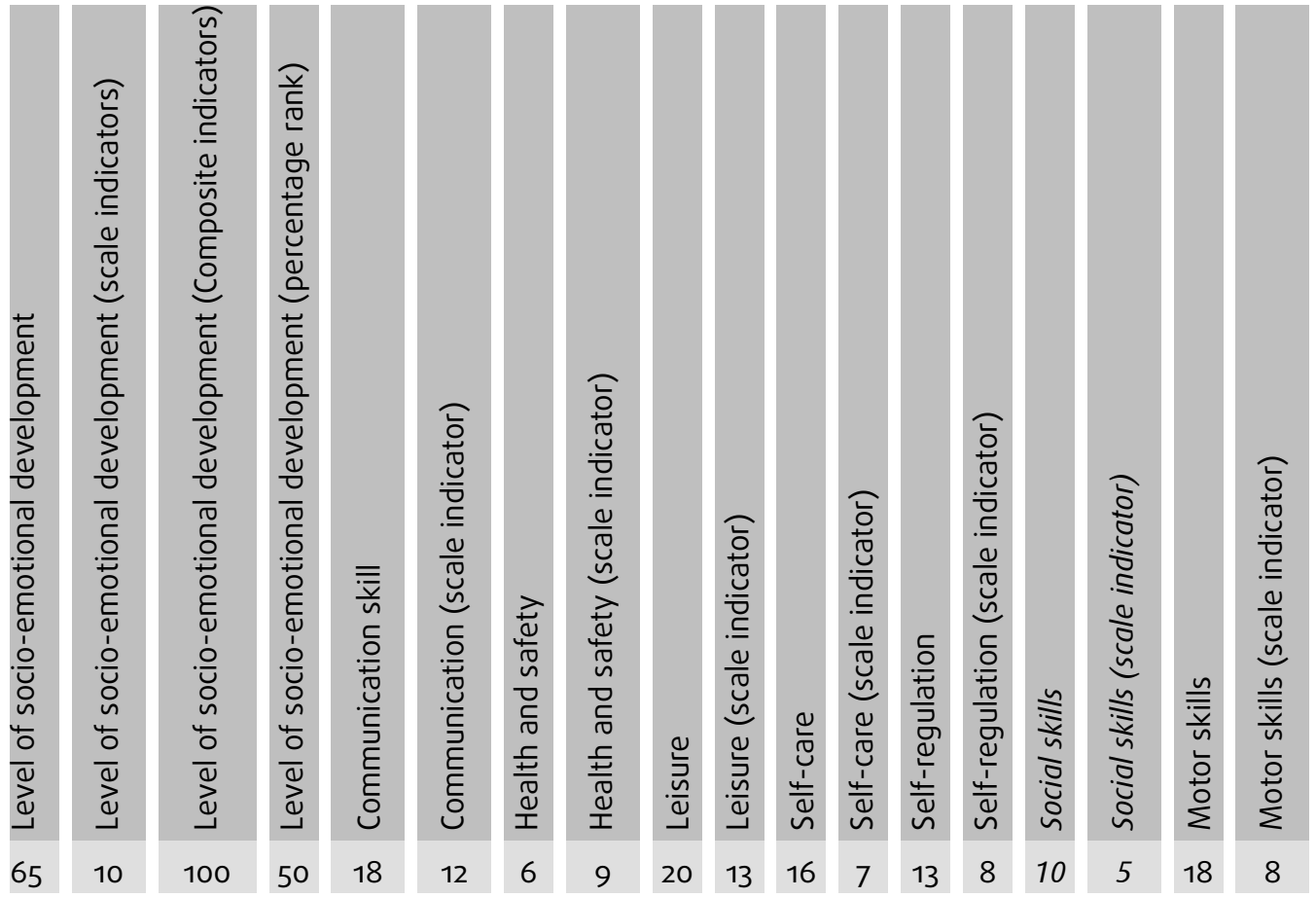

Adaptive behavioral skill «Social setting» includes the following: «smiles when sees the parent», «squeals/laughs, when happy or contended», «relaxes the body when is taken in parent's arms (cuddles)»; «holds up its hands when wants to be taken in parent's arms», "shows a sense of humor», "shows a special closeness/connection with parents», etc. (as the skill develops).

Let us consider an example.

A boy, aged 07 months 01 day, has an older sibling with a confirmed diagnosis of ASD.

The mother's results during $\mathrm{PCl}$ : emotionality 2 points, directiveness 1,5 points, initiative 3 points, interaction support 2 points, responsiveness 2 points, level of involvement/mobility 2,5 points. General adequacy of interaction is 13 points in total.

As can be seen from the table, the child has average indexes in the main categories (the lower border is seven points). However, when it comes to "social setting», the child has lower results than normal for this age.

Consequently, such a child-parent interaction with the risk of ASD/ADHD as following infant behavior, adjustment to it, forms a more developed skill of social interaction at the early stage of development (6,2 months).

The data obtained regarding the influence of parent-child interaction does not contradict existing research, for example, C.M. Harker, L.V. Ibanez [20] discovered that in 
groups with a higher risk of ASD and normally developing children, at the age of 9 months a higher level of mother's responsiveness correlated with the highest level of social smile [20]. M.W. Wan, J. Green, et al. [21] in their study ascertain that parent interaction with children with the high risk of ASD is connected to more directive and less responsive behavior compared to parents of children with the low risk of ASD.

It is necessary to conduct further study to clarify what can be the cause for higher directiveness of parents of children with the high family risk of ASD/ADHD.

The following hypotheses are set forth:

1. Interaction can, first and foremost, reflect atypical behavioral peculiarities of a child with ASD;

2. It is possible that parents of children with a high family risk of ASD show signs of autistic traits themselves which explains their special behavior;

3. Parents who have older children with ASD (those are the ones who, as a rule, take part in studies) are likely to change their behavior based on their experience of communication with older children and transfer it to the younger ones who have no disorders.

This study is a pilot and requires analysis of the results of a bigger sample. However, parent behavior and care about the child are clearly connected with the indicators of socio-emotional development of young children who have family risks of atypical development.

\section{Funding}

This research was supported by the Russian Foundation for Basic Research [Grant No. 17-36-01100].

\section{References}

[1] Andreeva, G. M. (2007). Social Psychology: A Textbook for Higher Educational Institutions. Moscow: Aspect Press. [Andreyeva, G. M. (2007). Sotsial'naya psikhologiya: uchebnik dlya vysshikh uchebnykh zavedeniy. M.: Aspekt Press (in Russia).]

[2] Aryan, M. A. (2017). Socio-emotional development of students learning by means of a foreign language. Language and Culture, no. 38, pp. 138-151. [Ariyan, M. 
A. (2017). Sotsial'no-emotsional'noye razvitiye obuchayushchikhsya sredstvami inostrannogo yazyka. YAzyk i kul'tura, no. 38, S. 138-151 (in Russian).]

[3] Baenskaia, E. R. (2007). Assistance in the Upbringing of Children with Special Emotional Development (Early Age), S. 108. Moscow: Terevinf. [Bayenskaya, Ye. R. (2007). Pomoshch' $v$ vospitanii detey so spetsial'nym emotsional'nym razvitiyem (ranniy vozrast), S. 108. Moskva: Terevinf (in Russian).]

[4] Bandura, A. (2000). The Theory of Social Learning, p. 320. St. Petersburg: Eurasia. [Bandura, A. (2000). Teoriya sotsial'nogo obucheniya, S. 320. Sankt-Peterburg: Yevraziya (in Russian).]

[5] Vygotsky, L. S. (1984). Collected works, in D. B. El'konin (ed.) 6v. V.4. Child Psychology, p. 432. M.: Pedagogika. [Vygotskiy, L. S. (1984). Sobraniye sochineniy, in D. B. El'konina (ed.) v 6 T. T.4. Detskaya psikhologiya, S. 432. M.: Pedagogika (in Russian).]

[6] Greenspan, S. and Wieder, S. (2017). Nates Engaging Autism: Using the Floortime Approach to Help Children Relate, Communicate, and Think, p. 512. Terevinf. [Greenspan, S. and Vider, S. (2017). Neyts s autizmom: ispol'zovaniye metodologii Floortime dlya razvitiya otnosheniy, obshcheniya i myshleniya, S. 512. Terevinf (in Russian).]

[7] Ilyin, E. P. (2001). Emotions and Feelings of St. Petersburg, p. 752. Peter with ill. [II'in, Ye. P. (2001). Emotsii i chuvstva Sankt-Peterburga, S. 752. Piter s: il (in Russian).]

[8] Lebedinsky, V. V. and Bardyshevskaya, M. K. (eds.) (2002). Affective development of a child in norm and pathology, in Psychology of Abnormal Child Development: Reader in 2 Volumes, pp. 588-681. T. I. - M: CheRo: High. Educ.: Publisher: Moscow State University. [Lebedinskiy, V. V. and Bardyshevskaya, M. K. (eds.) (2002). Affektivnoye razvitiye rebenka $v$ norme i patologii, in Psikhologiya anomal'nogo razvitiya rebenka: Chitatel' v 2 tomakh, pp. 588-681. T. I. - M: CheRo: Prodvinutyy. Izdatel'stvo: Moskovskiy gosudarstvennyy universitet (in Russian).

[9] Lorenz, K. (2008). On Aggression (translated from German - A. I. Fedorova, Cultural Revolution. M. [Lorentz, K. (2008). Tak nazyvayemoye zlo (translated s nim. - A. I. Fedorov, Kul'turnaya revolyutsiya. M. (in Russian).]

[10] Lorentz, K. (1998). Behind the mirror: A search for a natural history of human knowledge (translated from German by A. I. Fedorova, A. V. Gladkogo (ed.), comp. A. V. Gladkov and A. I. Fedorov, after A. I. Fedorova Thinkers of the XX century, P. 393. Moscow: Republic. [Lorentz, K. (1998). Obratnaya storona zerkala (translated A.I. Fodorova; Izdaniye A. V. Gladkogo; sost. A. V. Gladkov, A. I. Fedorov; posle. A.I. Fedorov Mysliteli XX veka, S. 393. Moskva: Respublika (in Russian).] 
[11] Luria, A. R. and Chomskaya, E. D. (1966). Frontal Lobes and Regulation of Mental Processes: Neuropsychological Studies, p. 740. Moscow: Publisher of Moscow University. p.:ill. [Luria, A. R. and Chomskaya, E. D. (1966). Lobnyye doli i regulyatsiya psikhicheskikh protsessov: neyropsikhologicheskiye issledovaniya, S. 740. Moskva: Izdatel'stvo Moskovskogo universiteta. s.:il (in Russian).]

[12] Krylov, A. A. (2005). Psychology: A Textbook (2nd edition), p. 234. Publishing house Prospekt. [Krylov, A. A. (2005). Psikhologiya: uchebnik (2-ye izdaniye), S. 235. Izdatel'skiy dom «Prospekt (in Russian).]

[13] Nikolaeva, E. I. and Merenkova, V. S. (2012). Modeling the prognosis of the child's health of the first years of life on the basis of his mother's psychophysiological characteristics in a small town. Psychology of Education in the Multicultural Space, vol. 2, no. 18, pp. 5-12. [Nikolayeva, Ye. I. and Merenkova, V. S. (2012). Modelirovaniye prognoza zdorov'ya rebenka pervykh let zhizni na osnove psikhofiziologicheskikh kharakteristik yego materi v usloviyakh malogo. Psikhologiya obrazovaniya $v$ polikul'turnom prostranstve, T. 2, no. 18, S. 5-12 (in Russian).]

[14] Pavlov, I. P. (1973). Twenty-year Experience of Objective Study of Higher Nervous Activity (behavior) of Animals. Moscow: Nauka. [Pavlov, I. P. (1973). Dvadtsatiletniy opyt ob"yektivnogo izucheniya vysshey nervnoy deyatel'nosti (povedeniya) zhivotnykh. M.: Nauka (in Russian).

[15] Piaget, J. (1969). Selected Psychological Works. M. [Piazhe, Z. H. (1969). Izbrannyye psikhologicheskiye proizvedeniyo. M. (in Russian).]

[16] Tokarckaya, L. V., Lavrova, M. A., and Lazauskene, Z. S. (2017). Studying the features of neurocognitive development and the specifics of parent-child interaction with the family risk of autism spectrum disorders (ASP) and attention deficit hyperactivity disorder (ADHD). Pedagogical Education in Russia, no. 11, pp. 136-144. [Tokarckaya, L. V., Lavrova, M. A., and Lazauskene, Z. S. (2017). Izucheniye osobennostey neyrokognitivnogo razvitiya i spetsifiki detsko-roditel'skogo vzaimodeystviya pri semeynom riske rasstroystv autisticheskogo spektra (RAS) i sindroma defitsita vnimaniya i giperaktivnosti (SDVG). Pedagogicheskoye obrazovaniye v Ros-sii, no. 11, S. 136-144 (in Russian).]

[17] Ainsworth, M. D., Blehar, M., Waters, E., et al. (1978). Patterns of Attachment: A Psychological Study of the Strange Situation. Hillsdale, NJ: Lawrence Erlbaum.

[18] Weiss, L. G., Oakland, T., and Aylward, G. (2010). Bayley-III Clinical Use and Interpretation, p. 240. Elsevier Inc.

[19] Bowlby, J. A. (1988). Secure Base: Clinical Applications of Attachment Theory, p. 196. Psychology Press. 
[20] Harker, M., Ibanez, L. V., Nguyen, T. P., et al. (2016). The effect of parenting style on social smiling in infants at high and low risk for ASD. Journal of Autism and Developmental Disorders, vol. 46, pp. 2399-2407r.

[21] Wan, M. W., Green, J., Elsabbagh, M., et al. (July 7, 2013). Quality of the interaction between at-risk infants and caregiver at 12-15 months is associated with 3-year autism outcome. Journal of Child Psychology and Psychiatry, and Allied Disciplines, vol. 54, pp. 763-771.

[22] Hopkins, B. (ed.) (2005). The Cambridge Encyclopedia of Child Development, p. 670, Associate Editors: Ronald G. Barr, George F. Michel, and Philippe Rochat. Cambridge University Press. 